\title{
USING IRON ORE WASTE AS AGGREGATE IN MAKING K. 300 QUALITY CONCRETE
}

\author{
Rajiman*1, Muhammad Amin², Harjianto Setiaji ${ }^{3}$ \\ ${ }^{1}$ Bandar Lampung University \\ ${ }^{2}$ Mineral Technology Research of Indonesian Institute of Sciences - LIPI \\ ${ }^{3}$ Sang Bumi Ruwa Jurai University \\ Korespondensi: rajimanmt@gmail.com
}

\begin{abstract}
The main component of concrete is cement, water, and aggregate (fine and rough aggregate), with aggregate constituting between $50 \%$ and $60 \%$ of total volume. Iron stone coming from nature is a material alternative that can be used as rough aggregate in making concrete. This research was conducted by sieving iron ores with sieving particle sizes of $2 \mathrm{~mm}, 2-5 \mathrm{~mm}, 5-8 \mathrm{~mm}$, and 10-12 mm. The compressive strength test was conducted at 7,14 , and 28 days. The iron ore waste from iron processing can be used as aggregate for K 300 quality concrete because the concrete compressive test result after 28 days by using sieving particle sizes of mesh 20 , mesh 5, mesh 8-10, and mesh 10-12 exceeded normal K 300 quality concrete with compressive strength scores of $30.12 \mathrm{MPa}, 38.90 \mathrm{MPa}, 36.75 \mathrm{MPa}$, and 32.10 Mpa respectively, while normal K 300 quality concrete had 28.86 $\mathrm{MPa}$ compressive strength.
\end{abstract}

Keywords: Aggregate, compressive strength, concrete, iron ore, material

\section{INTRODUCTION}

Concrete is a composite building material made from a combination of aggregate and bonding cement. It is a composite material made from aggregate bonding with liquid cement that is hardening overtime [1]. Concrete main components are cement, water, and aggregate (fine and rough aggregate) with aggregate constituting between $50 \%$ and $60 \%$ of total volume. Aggregate is the most mined material in the world and natural mineral particles function as filing material in the mix of cement or mortar [2]. Aggregate is responsible for unit weight, modulus elasticity and stability of concrete dimension because these characteristics depend on aggregate physical characteristics (strength and bulk density) [3]. The common rough aggregate in making concrete comes from andesite stone grinded with stone crusher and differentiated based on its sizes. The andesite stone currently is used widely as aggregate for construction sector, especially infrastructures for roads, bridges, buildings, and other facilities [4], but andesite stone deposit is continuously decreasing because of continuous production. Reports of
Integrated Office for Investment and Service of Lampung province showed that concerning natural resource in Lampung, andesite stone mining in Lampung reached 1,980,000,000 $\mathrm{m}^{3}$ in 2017 and the production has been increasing so that andesite stone deposit is decreasing. Therefore, alternative replacements for andesite stone as rough aggregate in making concrete are required.

Iron ore coming from nature is one of alternative materials that can be used as rough aggregate in making concrete beside stone. According to Balance of Metal and Non-metal Mineral Natural Sources from Geology Resource Center in 2008, the primary iron ore source in Indonesia was 3,257,171,469 tons and reserve deposit of $87,228,005$ tons.

There was a research [5] on becoming laterite iron ore as find aggregate to replace sand with the aggregate sizes of $19.5 \mathrm{~mm}, 12.5 \mathrm{~mm}$, $9.5 \mathrm{~mm}, 5.0 \mathrm{~mm}$, and $2.36 \mathrm{~mm}$ with $1: 2: 4$ ratio composition (cement : laterite iron ore : granite) and water-cement ratio of 0.6 . The iron ore replaced sand by $25 \%$ and $50 \%$. The testing result showed that $25 \%$ laterite content mixture by using rough aggregate sizes of $19.5 \mathrm{~mm}$ and 
$12.5 \mathrm{~mm}$ showed slum scores of $80 \mathrm{~mm}$ and 65 $\mathrm{mm}$. It indicated that more water was needed for smaller sizes of rough aggregate to obtain medium work capability because of their surface width. However, for rough aggregate with 2.36 $\mathrm{mm}, 5.0 \mathrm{~mm}$, and $2.36 \mathrm{~mm}$ with $50 \%$ laterite content, the slum score decreased to $0 \mathrm{~mm}$, and this showed a rigid consistence because of laterite iron ore affinity for water and because of wider surface wide related to smaller particle size of the rough aggregate. The compressive strength result showed that the concretes were all normal with all granite particle sizes including $0 \%$ of laterite content with a peak compressive strength of $16 \mathrm{~N} / \mathrm{mm}^{2}$ at 7 days and $24.44 \mathrm{~N} / \mathrm{mm}^{2}$ at 28 days. Meanwhile, the concrete with maximum laterite content of 50\% produced minimum strength of $14.2 \mathrm{~N} / \mathrm{mm}^{2}$ at 7 days and $20.00 \mathrm{~N} / \mathrm{mm}^{2}$ at 28 days. This indicated that the compressive strength decreased along with increasing laterite content in the concrete [5].

A research on using hematite iron ore as aggregate with maximum particle size of 20.0 $\mathrm{mm}$ with mixture of cement, sand, made into concretes of $150 \times 150 \times 150 \mathrm{~mm}$ size and tested at 7,28 , and 56 days, produced $28.1 \mathrm{~N} / \mathrm{mm}^{2}$ compressive strength at 7 days, 49.777828 .1 $\mathrm{N} / \mathrm{mm}^{2}$ at 28 days, $53.92628 .1 \mathrm{~N} / \mathrm{mm}^{2}$ at 56 days, and porosity $2.19 \%$ at 28 days [6]. A research on characteristics of concrete mixed with iron ore tailings or material coming from iron ore processing waste in form of granules that are mixed into the concrete to replace natural sand with concentration of $0 \%, 25 \%$, $35 \%$, and $45 \%$. The concrete slum test result showed that the more iron ore waste was added, then the slump score would be lesser. The compressive strength test result of concrete with $150 \times 150 \times 150 \mathrm{~mm}$ cube size showed that the longer the sample age, then the stronger the compressive strength would be. The compressive strength in 3 days was $17 \mathrm{MPa}$ at $0 \%, 15 \mathrm{MPa}$ at $25 \%, 17 \mathrm{MPa}$ at $35 \%$, and 14 MPa at $45 \%$. The compressive strength in 7 days was $27 \mathrm{MPa}$ at $0 \%, 26.5 \mathrm{MPa}$ at $25 \%, 28 \mathrm{MPa}$ at $35 \%$, and $25 \mathrm{MPa}$ at $45 \%$. The compressive strength in 28 days was $40 \mathrm{MPa}$ at $0 \%, 39 \mathrm{MPa}$ at $25 \%, 41 \mathrm{MPa}$ at $35 \%$, and $38 \mathrm{MPa}$ at $45 \%$ [7].

There was a research on making $\mathrm{K} 200$ concrete with $\mathrm{w} / \mathrm{c}$ ratio $=0.61$ by using materials from Lampung as aggregates; they were lime stone, feldspar stone, basalt stone, granite stone, and slag from iron ore smelting. The aggregates to use were differentiated based on their types; type $\mathrm{A}=5-15 \mathrm{~mm}$, type $\mathrm{B}=15-25 \mathrm{~mm}$, and type $\mathrm{c}=25-50 \mathrm{~mm}$. The compressive strength test was conducted at 21 days and the highest result was obtained by using basalt stone aggregate. They were $24.74 \mathrm{MPa}$ for type A, 21.20 MPa for type $\mathrm{B}$, and $20.70 \mathrm{MPa}$ for type $\mathrm{C}$. The smallest compressive strength was obtained by using lime stone at $8.58 \mathrm{MPa}$ for type C. [8]

\section{RESEARCH METHOD}

This research used literary study and experiment methods. Literary study method was used to see references related to this research, while experiment method was done by preparing research materials in forms of iron ores, sand, and cement. Iron sand was sieved according to desired particle sizes: passing sizes of $2 \mathrm{~mm}, 2 \mathrm{~mm}, 5 \mathrm{~mm}, 8-10 \mathrm{~mm}$, and 10-12 mm. Sieved iron ores were mixed with sand, cement, and water and then concrete cube samples for testing were made with $150 \times 150 \times 150 \mathrm{~mm}$ dimension. The reserachesign used iron ore waste as aggregate in making concrete.

\subsection{Materials and Equipment}

Equipment in this research were Gold series ohaus brand digital scale, memmert brand oven, pyrex $25 \mathrm{~mL}$ measuring cup, Pyrex $50 \mathrm{~mL}$ pycnometer, 1 set of multilevel siever, Wykeham Farrance Engineering brand compressive strength test machine made in England model 55104 with capacity of $1500 \mathrm{kN}, \mathrm{pH}$ indicator, bucket, spatula, gloves, concrete mixer, beaker glass, Pyrex made in Thailand $(500 \mathrm{~mL}, 100$ $\mathrm{mL}, 50 \mathrm{~mL}$ ), $15 \mathrm{~cm} \times 15 \mathrm{~cm}$ cube molding, Five Goat brand analog scale made in China with capacity of $5 \mathrm{~kg}$, Sartorius brand analytic weighing balance, XRF device, and SEM-EDS device. Materials in this research were Portland Cement Composite type I produced by PT. Semen Padang Indonesia, water from laboratory of chemical and non-metal analysis from Mineral Technology Research office (BPTM) in South Lampung district, iron ores and sand from Tanjung Bintang.

\subsection{Experiment Procedure}

The procedure of mortar making was as follows. Preparing iron ore waste material, and then it was sieved by the following particle sizes; passing $2 \mathrm{~mm}, 2 \mathrm{~mm}, 8-10 \mathrm{~mm}$, and 10$12 \mathrm{~mm}$. Each of them was chemically analyzed by using XRF. Prparing concrete making 
materials; sand, water, Portland cement composite type I produced by PT. Semen Padang Indonesia, and iron ore according to their respective particle sizes. Scaling each material with composition ratio based on SNI 03-2834-2000 for K 300 quality and water/cement ratio or FAS $=0.52$, with the following respective composition; $413 \mathrm{~kg}$ of portland cement, $681 \mathrm{~kg}$ of sand, $1021 \mathrm{~kg}$ of gravel or iron ore aggregate, 215 liter of water. If the mix was made in $10 \mathrm{~kg}$, the composition would be $1.773 \mathrm{~kg}$ of cement, $2.922 \mathrm{~kg}$ of sand, $4.382 \mathrm{~kg}$ of aggregate, and 0.923 liter of water. The concrete mixture from respective composition was stirred by using concrete mixer. Mixing was done evenly for \pm 15 minutes followed by watering into the concrete mixture with an objective to make the composition soft to reduce cracking. The mix was then tested with slump test. The mix was poured into molding device with $15 \mathrm{~cm} \times 15 \mathrm{~cm} \times 15 \mathrm{~cm}$ size while stabbed repeatedly by using taper iron stick to make the mix evenly filling the mold and then it was left aside for 24 hours from the time it was molded. The testing object was entered into a water container for wet curing. Water temperature was set to be room temperature at $23^{0}$ to $32^{\circ} \mathrm{C}$.the compressive strength test was done by using standard of ASTM C 39-86 (1993) at 7, 14, and 28 days. The concrete then was tested physically and chemically with compressive strength test, absorption test, specific gravity test, and XRF chemical analysis.

\section{RESULT AND DISCUSSION}

\subsection{The Raw Material Testing}

Cement type PCC and OPC testing results by using can be seen in Table 1 . Table 1 shows that $\mathrm{CaO}$ compound content at PCC cement is $58.66 \%$, and it is lesser than at OPC cement $(63.12 \%) . \mathrm{CaO}$ in cement is a dominant element coming from lime stone raw material. The $\mathrm{Cao}$ content is very influential to the drying speed of the cement mix or concrete. The higher is the $\mathrm{CaO}$ content, then the faster would be the drying process. The use of lime stone can also improve sustainability of building material and reduce clinker component that consumes the most energy and produces the most $\mathrm{CO}_{2}$ during manufacture process [9].
However, PCC cement is a type of cement that is widely used for building housing. Bridge, office, etc., but this PCC cement is not recommended for high multilevel buildings because its quality is lower than OPC type, that can be used for all types of constructions and infrastructures. This is because $\mathrm{CaO}$ content is very influential in cement when it reacts with water to create Calcium Silicate Hydrate (CSH), and the use of lime stone accelerates CSA cement hydration [9]. Pelletier-Chaignat et.al. suggest that the use of lime stone would be more effective in improving CSA cement strength compared to quartz powder [10].

Table 1. Cement type PCC and OPC testing results

\begin{tabular}{r|l|c|c}
\hline No. & $\begin{array}{l}\text { Chemical } \\
\text { composition type }\end{array}$ & $\begin{array}{c}\text { Type PCC } \\
(\%)\end{array}$ & $\begin{array}{c}\text { Type OPC } \\
(\%)\end{array}$ \\
\hline 1 & $\begin{array}{l}\text { Silicon Dioxide } \\
\left(\mathrm{SiO}_{2}\right)\end{array}$ & 23,13 & 18,69 \\
2 & $\begin{array}{l}\text { Aluminum Oxide } \\
\left(\mathrm{Al}_{2} \mathrm{O}_{3}\right)\end{array}$ & 8,76 & 5,00 \\
\hline 3 & Ferro Oxide $\left(\mathrm{Fe}_{2} \mathrm{O}_{3}\right)$ & 4,62 & 3,49 \\
\hline 4 & Calcium Oxide $(\mathrm{CaO})$ & 58,66 & 63,12 \\
\hline 5 & $\begin{array}{l}\text { Magnesium Oxide } \\
(\mathrm{MgO})\end{array}$ & 0,90 & 1,09 \\
\hline 6 & Sulfur Trioxide $\left(\mathrm{SO}_{3}\right)$ & 2,18 & 2,95 \\
\hline 7 & $\begin{array}{l}\text { Loss on ignition } \\
(\text { LOI) }\end{array}$ & 1,69 & 3,56 \\
\hline 8 & Free lime & 0,69 & 1,27 \\
\hline 9 & Undissolved part & 8,82 & 0,36 \\
\hline
\end{tabular}

The XRF analysis result of iron ore material as aggregate according to its respective particle size can be seen in Table 2. Iron ore is a mineral coming from nature that is dominated by iron element and other impurity elements. Iron ore can be used as aggregate. Based on XRF testing result, Table 2 shows that sthe bigger the aggregate size, then the higher the Fe content will be. The Fe content is $38.246 \%$ for < $2 \mathrm{~mm}$ aggregate size, $47.460 \%$ for $2-5 \mathrm{~mm}$ size, $49.330 \%$ for $5-8 \mathrm{~mm}$ size, $58.660 \%$ for $8-10$ mesh aggregate and $69.225 \%$ for $10-12$ mesh aggregate. The bigger is the aggregate size, then the higher is the Fe content. The bigger aggregate contains lower soil content at the iron ores or is cleaner, so that the iron ore is more dominated by $\mathrm{Fe}$. Soil existence at aggregate contaminate cement and it influences cement strength. A research result shows that soil addition to cement can also improve cement strength provided at particular soil amount added at drying and certain contamination amount [11]. 
Table 2. Iron ore aggregate XRF testing result

\begin{tabular}{c|c|c|c|c|c}
\hline \multirow{2}{*}{$\begin{array}{c}\text { Chemical } \\
\text { element }\end{array}$} & \multicolumn{5}{|c}{ Aggregate size (mm) } \\
\cline { 2 - 6 } & $<\mathbf{2}$ & $\mathbf{2 ~ - ~ 5}$ & $\mathbf{5 - 8}$ & $\mathbf{8} \mathbf{~ 1 0}$ & $\mathbf{1 0 ~ - ~ 1 2}$ \\
\hline $\mathrm{Fe}$ & 38,346 & 47,460 & 49,330 & 58,660 & 69,225 \\
\hline $\mathrm{Si}$ & 3,847 & 5,216 & 3,567 & 5,788 & 1,416 \\
\hline $\mathrm{K}$ & 2,528 & 2,211 & 3,500 & 1,554 & 1,317 \\
\hline $\mathrm{Al}$ & 1,372 & 2,163 & 1,640 & 2,444 & 1,875 \\
\hline $\mathrm{Cl}$ & 1,525 & 1,185 & 1,319 & 1,295 & - \\
\hline $\mathrm{Ca}$ & 0,406 & 0,878 & - & - & - \\
\hline $\mathrm{Mg}$ & - & - & 6,198 & 7,901 & - \\
\hline $\mathrm{Ti}$ & - & - & - & - & 1,065 \\
\hline $\mathrm{S}$ & - & - & - & - & 0,864 \\
\hline
\end{tabular}

The sand to use in this research came from Pasir Sakti village, Labuhan Maringgai of East Lampung district. The physical testing result of Labuhan Maringgai sand can be seen in Table 3.

Table 3. The physical testing result of sand as fine aggregate

\begin{tabular}{c|c|c|c|c}
\hline No. & Test & $\begin{array}{c}\text { Percen } \\
\text { tage }\end{array}$ & $\begin{array}{c}\text { Stand } \\
\text { ard }\end{array}$ & $\begin{array}{c}\text { Descriptio } \\
\text { n }\end{array}$ \\
\hline 1. & $\begin{array}{c}\text { Sand gradation } \\
\text { (fine granular } \\
\text { modulus) }\end{array}$ & 2.3 & $\begin{array}{c}2.2- \\
3.2\end{array}$ & qualified \\
\hline 2. & Specific gravity & 2.03 & - & $\begin{array}{c}\text { Mild } \\
\text { aggregate }\end{array}$ \\
\hline 3. & Slump content & $4.56 \%$ & $\leq 5 \%$ & $\begin{array}{c}\text { qualified } \\
\text { acceptable } \\
\text { humidity }\end{array}$ \\
\hline 4. & Water content & $0.45 \%$ & - & qualified \\
\hline 5. & Sand absorption & $6 \%$ & $\begin{array}{c}13.27 \\
\%\end{array}$ & \\
& & & & \\
\hline
\end{tabular}

Table 3 shows the sand testing result as fine aggregate. The sand from Labuhan Maringgai belongs to fine sand with 2.3 fine granular modulus (FGM) and it satisfies a standard of becoming fine aggregate in concrete making. The sand granule size distribution influences mortar strength. When the granule has uniform size, then sand pore volume will be bigger. Oppositely, when the sand granule size varies, sand pore volume will be lower. This is because smaller size granules will fill pores between bigger granules, so that the pores will be lesser (high density) [12]. Aggregate fineness or roughness can influence concrete workability. If there is too much fine aggregate in the concrete, it will cause thin layer of fine aggregate and cement will rise up influencing the cement reactivity, so that it will be very suitable to be fillers, to reduce initial porosity of the mixture and to improve concrete final strength [13]. The slump content also meets the standard by $4.56 \%$, while the standard is below $5 \%$. It is because the sand coming from the beach is by sucking method has already be clean because of mixed with water, so that the sand is free from excessive slump content. The good aggregate must be strong, durable, and clean. The excessive slump and other impurity particle contents shall reduce bonding between cement paste and its aggregate. Aggregate strength provides an important influence to concrete strength and the characteristics of an aggregate shall influence concrete durability and strength [14].

Rough aggregate can be produced from nature and artificially. Coral stone is an example of natural rough aggregate. Artificial rough aggregate can be produced from andesite stone crushing and limestone. This research used iron ore from Karnataka, India, as the rough aggregate that has the following chemical composition; $\mathrm{Fe}=63.84 \%, \mathrm{SiO}_{2}=2.64 \%, \mathrm{Al}_{2} \mathrm{O}_{4}$ $=3.98 \%, \mathrm{CaO}=0.14 \%$, and $\mathrm{MgO}=0.08 \%$. The reason to select iron ore as the rough aggregate was that because it had irregular shape, rough and sharp surface, durable against wheatear and indestructible, high hardness index by 5.5-6.5 Mohs scale, and gradation resistance [15]. The iron ore testing result and material requirements as rough aggregate based on ASTM C35-37 can be seen in Table 4.

Table 4 shows that slump content of iron ore aggregate with sizes less than $2 \mathrm{~mm}$ and 2-5 $\mathrm{mm}$ exceed required threshold, while for $5-8$ $\mathrm{mm}, 8-10 \mathrm{~mm}$, and $10-12 \mathrm{~mm}$ sizes still satisfy the requirement. It is because finer iron ore aggregate will be mixed with fine soil that enter into aggregate pores, so that when the aggregate is washed, soil will be cleansed by water as slump. Bigger size aggregate contain less attached soil, so that not much soil enter into aggregate pores and lesser soil will be cleansed by water and the slump content will be lower. The slump content is very influential at the concrete making process, because much more slump content will cause concrete cracks. It also influences absorbed water content at the aggregate, because the more slump content at the aggregate will make more water absorbed by the slump, while the more aggregate water absorption will cause longer time for concrete drying. 
Table 4. Physical testing result of iron ore base on aggregate size

\begin{tabular}{l|c|c|c|c|c|c}
\hline \multirow{2}{*}{ Aggregate testing } & \multicolumn{5}{c|}{ Iron ore aggregate size (mm) } & ASTM C 35-37 \\
\cline { 2 - 6 } & $<\mathbf{2}$ & $\mathbf{2 ~ - 5}$ & $\mathbf{5 - 8}$ & $\mathbf{8 ~ - ~ 1 0}$ & $\mathbf{1 0}-\mathbf{~ 1 2}$ & \\
\hline Specific gravity $\left(\mathrm{g} / \mathrm{cm}^{3}\right)$ & 2.35 & 2.51 & 2.55 & 2.59 & 2.63 & $2.5-2.7$ \\
\hline Slump content $(\%)$ & 13.09 & 9.93 & 3.09 & 0.41 & 0.11 & Max. 5 \\
\hline Water absorption (\%) & 23.19 & 21.86 & 6.42 & 5.49 & 3.37 & $2-7$ \\
\hline Solid volume weight & 2.43 & 2.61 & 2.67 & 2.72 & 2.76 & $>1.2$ \\
\hline
\end{tabular}

\subsection{Concrete Product Testing Result}

3.2.1 The concrete slump testing (based on SNI 1972: 2008)

The objective of slump testing is to find out the concrete mix thickness and workability. It is related to whether water mixed into concrete mix is either too watery or not. Too much water mixed into the concrete will influence concrete strength and longer drying time. The concrete slump testing result can be seen in Table 5.

Table 5. Concrete slump testing based on iron ore aggregate sizes

\begin{tabular}{c|c|c}
\hline No. & Aggregate size (mm) & $\begin{array}{c}\text { Slump test result } \\
(\mathbf{c m})\end{array}$ \\
\hline 1. & $<2$ & 1.2 \\
\hline 2. & $2-5$ & 1.7 \\
\hline 3. & $5-8$ & 2.1 \\
\hline 4. & $8-10$ & 2.3 \\
\hline 5. & $10-12$ & 2.5 \\
\hline
\end{tabular}

The slump scores according to aggregate sizes in Table 5 indicate that the higher is the aggregate size, then the higher will be the slump score or in other words the bigger concrete decadence score measured by Abrams device. In addition, other factors that influence slump score are aggregate type, aggregate size, aggregate absorption, water amount or water ratio compared to cement, and whether aggregate surface is smooth or rough [16]. The higher is the aggregate size, then the higher the slump score. It is caused by the aggregate granule gradation changes that influence concrete workability. Bigger aggregate granule will produce higher workability, because bigger granule tends to have smaller friction, so that the same composition will need more water, the mix becomes more watery. A concrete mix with smaller aggregate size will have wider surface area with greater friction, so that it will make more rigid mix [17], and this will influence concrete decadence score [18]. The bigger aggregate size require lesser water [19] so that it will proportionate with the fresh concrete workability with constant cement/water ratio
[20]. Smaller aggregate size will have wider surface area and bigger friction, and will require more water, and the mix becomes rigid while temperature and mixing speed also influence the slump score [21]. Table 4 shows that concrete with aggregate sizes $<2 \mathrm{~mm}, 2-5 \mathrm{~mm}, 5-8 \mathrm{~mm}$, 8-10 $\mathrm{mm}$, and 10-12 $\mathrm{mm}$ have slump scores of $1.2 \mathrm{~mm}, 1.7 \mathrm{~mm}, 2.1 \mathrm{~mm}, 2.3 \mathrm{~mm}$ and $2.5 \mathrm{~mm}$ respectively. All of them satisfy the requirement standard for road and foundation construction (slump score for road $=0-25 \mathrm{~mm}$; slumps score for foundation $=10-40 \mathrm{~mm}$ ). Meanwhile, according to ACI standard, only concrete with aggregate size of 10-12 mm with slump score 25 $\mathrm{mm}$ will satisfy ACI standard. Concrete compressive strength test (ASTM C 579-01, 2001).

The objective of concrete compressive strength is to find out the magnitude of load per width unit before finally the testing object be crushed by a particular load produced by compressive strength machine. The compressive strength test result for the concrete using iron ore aggregate can be seen in Table 6 .

Table 6. The compressive strength test result of concrete based on iron ore aggregate sizes

\begin{tabular}{|c|c|c|c|c|}
\hline \multirow[t]{2}{*}{ No. } & \multirow{2}{*}{$\begin{array}{l}\text { Aggregate size } \\
\qquad(\mathrm{mm})\end{array}$} & \multicolumn{3}{|c|}{$\begin{array}{c}\text { Compressive strength test } \\
\text { result }(\mathrm{MPa})\end{array}$} \\
\hline & & $\begin{array}{l}7 \text { days } \\
\text { age }\end{array}$ & $\begin{array}{l}14 \text { days } \\
\text { age }\end{array}$ & $\begin{array}{c}28 \text { days } \\
\text { age }\end{array}$ \\
\hline 1. & $<2$ & 21.73 & 26.82 & 30.12 \\
\hline 2. & $2-5$ & 28.18 & 32.44 & 38.90 \\
\hline 3. & $5-8$ & 26.21 & 31.98 & 36.75 \\
\hline 4. & $8-10$ & 25.26 & 29.36 & 35.66 \\
\hline 5. & $10-12$ & 22.77 & 26.89 & 32.10 \\
\hline 6. & $\begin{array}{c}\text { Standard for } \\
\text { normal } \\
\text { concrete }\end{array}$ & 18.49 & 22.74 & 28.86 \\
\hline
\end{tabular}

Table 6 shows concrete with bigger size of iron or aggregate will have lower compressive strength score compared to the one using smaller size of iron ore aggregate. It is because the influence of aggregate size gradation to concrete density and porosity levels. A good gradation shall produce 
maximum density and minimum porosity. Aggregate gradation role is a factor that must be consider. A good gradation is the continuous gradation where all granule sizes in an aggregate will create heterogenic granules. Heterogenic granules shall mutually filling empty pores according to their respective sizes [17]. Table 6 shows that concrete with aggregate size $<2 \mathrm{~mm}$ has compressive strength of $21.73 \mathrm{MPa}$, while concrete with aggregate size of 2-5 $\mathrm{mm}$ has an increased compressive strength score of 28.18 MPa. However, the scores decrease at concretes with aggregate sizes of 5-8 mm, 8-10 mm, and $10-12 \mathrm{~mm}$ by $26.21 \mathrm{MPa}, 25.26 \mathrm{MPa}$, and 22.77 MPa respectively at 7 days. Nevertheless, their compressive strength scores are stronger than standard concrete with compressive strength of $18.49 \mathrm{MPa}$. The bigger is the concrete aggregate size, then the lower is the concrete compressive strength, and vice versa [19]. It also applies with concrete ages at 14 and 28 days. Besides aggregate size, the concrete age also influence concrete compressive strength. The longer is the concrete age for testing, then the higher is the concrete compressive strength. This is influenced by hydration reaction occurring the cement. The compressive strength scores of 14 days concrete age according to aggregate sizes in order are the following; $26.82 \mathrm{MPa}$ at $<2 \mathrm{~mm}$ aggregate size, $32.44 \mathrm{MPa}$ at 2-5 $\mathrm{mm}$ aggregate size, $31.98 \mathrm{MPa}$ at 5-8 $\mathrm{mm}$ aggregate size, 29.36 $\mathrm{MPa}$ at $8-10 \mathrm{~mm}$ aggregate size, and $26.89 \mathrm{MPa}$ at $10-12 \mathrm{~mm}$; while standard concrete compressive strength is $22.79 \mathrm{MPa}$ at testing after 14 days. The compressive strength scores of 28 days concrete age according to aggregate sizes in order are the following; $30.12 \mathrm{MPa}$ at < $2 \mathrm{~mm}$ aggregate size, $38.90 \mathrm{MPa}$ at $2-5 \mathrm{~mm}$ aggregate size, $36.75 \mathrm{MPa}$ at $5-8 \mathrm{~mm}$ aggregate size, $35.66 \mathrm{MPa}$ at $8-10 \mathrm{~mm}$ aggregate size, and $32.10 \mathrm{MPa}$ at $10-12 \mathrm{~mm}$; while standard concrete compressive strength is $28.86 \mathrm{MPa}$ at testing after 28 days. The concrete compressive strength improvement by using iron are aggregate is because iron ore particle density can reduce concrete porosity, so that when soaking maintenance is done, it will improve $\gamma$ ray [22]. In addition, concrete porosity is also related to concrete absorption score. The higher is the concrete porosity, then the higher is the water absorption. Concrete porosity and absorption are also influenced by aggregate sizes that finally affect the compressive strength. The bigger aggregate size will have wider pores that influence the concrete density. Because, while cement is binding aggregate granules, some aggregate are left unbound, so that they create pores that create concrete pores [23][24]. Cavities in the concrete are caused by air bubbles created during concrete molding. These bubbles is created by excessive water use, or by bigger water ratio than cement. These excessive water will use some concrete spaces and when the concrete has dried and hardened, it will leave concrete cavities and finally the concrete is less dense. This influences the concrete compressive strength. The water/cement ratio used in this research was in normal limit by 0.52 , so that the produced compressive strength scores were still above compressive strength of normal concrete by $18.49 \mathrm{MPa}$ at 7 days, $22.74 \mathrm{MPa}$ at 14 days, and $28.86 \mathrm{MPa}$ at 28 days. The bigger is the aggregate size, then the lower is the compressive strength score [20].

\subsection{Concrete Porosity Test (SNI 1969-2008)}

The objective of concrete porosity test is to find out the amount of water absorbed by concrete. This is influenced by cavities inside the concrete. The more pores in concrete will cause wider surface width, and the more water will be absorbed. This is caused by incorrect material composition and quality in concrete making. The concrete porosity scores according to aggregate sizes are presented in Table 7.

Table 7. Concrete porosity test result according to aggregate sizes at 28 days

\begin{tabular}{l|c|c}
\hline No. & Aggregate sizes (mm) & $\begin{array}{c}\text { Absorption test result } \\
(\%)\end{array}$ \\
\hline 1. & $<2$ & 5.70 \\
\hline 2. & $2-5$ & 3.65 \\
\hline 3. & $5-8$ & 5.78 \\
\hline 4. & $8-10$ & 6.46 \\
\hline 5. & $10-12$ & 7.12 \\
\hline 6. & Normal concrete & 7.24 \\
\hline
\end{tabular}

Table 7 shows that the highest concrete porosity score by $7.12 \%$ against water is obtain by the concrete using aggregate size of 10-12 $\mathrm{mm}$. Other concrete porosity scores by using aggregate sizes of mesh 2-5, mesh 5-8, mesh 810 and mesh $10-12$ are increasing at $3.65 \%$, $5.78 \%, 6.46 \%$ and $7.12 \%$ respectively. Porosity score of concrete using aggregate size of mesh 20 is higher $(5.70 \%)$ compared to the concrete using aggregate size less than mesh 20 . Concrete porosity score increases along with bigger aggregate size, because aggregate size influence 
pores or cavities created inside the concrete. The bigger the aggregate size is, then the bigger is the cavity in the concrete. This makes concrete absorbing more concrete and this influences the concrete quality. The bigger is the concrete porosity, then the weaker is the compressive strength score. Concrete porosity is also influenced by hydration reaction result between cement and water [25]. However, all absorption scores in this research are still better compared to standard concrete absorption $(7.24 \%)$, while required concrete absorption score is maximum $6.5 \%$. Therefore, the absorption score of concrete using aggregate size of mesh $10-12 \mathrm{~mm}$ exceeds the maximum requirement of concrete absorption by $7.12 \%$.

\section{CONCLUSION}

Iron ore waste from iron ore processing can be used as aggregate in making K 300 quality concrete because the compressive strength testing results at 28 days exceed normal K 300 concrete compressive strength by 28.86 $\mathrm{MPa}$. The compressive strength scores of the concrete using iron ore aggregate sizes of mesh 20, mesh 20, mesh 5, mesh 8-10 and mesh 10$12 \mathrm{~mm}$ are $30.12 \mathrm{MPa}, 38.90 \mathrm{MPa}, 36.75 \mathrm{MPa}$, and 32.10 MPa respectively.

\section{REFERENCES}

[1] Woodford, C. (2016). Concrete and reinforced concrete.

http://www.explainthatstuff.com/steelconcret e.html. Accessed November, 2016.

[2] Habboud. 2011. Effect of Mineral Admixtures on Properties of Self-Compacting. Cambridge Press : United States

[3] Anonymous, (2012). Functions and requirements of ingredients of cement concrete. http://weebo.hubpages.com/hub/Functionsand-requirementsof-ingredients-of-cementconcrete. Accessed October, 2017

[4] Nandi, Susanto. 2010. Pemanfaatan Batuan Vulkanik Andesit Sebagai Perancangan Bahan Bangunan Beton Mix Design. Jurnal Teknik Sipil. Vol 10. Hal 22-26

[5] Naruboina Siva Khrisna and Sri Chandana, 2015, The Use of Basalt Aggregate as Coarse Aggregate in Sigh Strength Concrete Mixes, International Journal \& Magazine of Engineering, Technology, Management and Reseach (IJMEeeb, TMR), Volume 2, issue 11, November, pp.850-854

[6] D. Ramachandran, R.P.George, Vinita Vishwakarma, Sudha.U, Arul Maximus Rabel1, Studies on mechanical and microstructural properties of hematite modified concrete, International Journal of ChemTech Research (IJCRGG), 2017, Vol.10 No.4, pp 464-472

[7] Zhong-xi Tian, Zeng-hui Zhao, Chun-quan Dai, and Shu-jie Liu, 2016, Experimental Study on the Properties of Concrete Mixed with Iron Ore Tailings, Hindawi Publishing Corporation Advances in Materials Science and Engineering Volume 2016, Article ID 8606505,9 pages

[8] Muhammad Amin, et al, 2017, The Material From Lampung As Coarse Aggregate To Substitute Andesite For Concrete-Making, Mineral Processing and Technology International Conference, Jakarta

[9] Martin, L.H.J.; Winnefeld, F.; Müller, C.J.; Lothenbach, B. Contribution of limestone to the hydration of calcium sulfoaluminate cement. Cem. Concr. Compos. 2015, 62, 204211.

[10] Pelletier-Chaignat, L.; Winnefeld, F.; Lothenbach, B.; Müller, C.J. Beneficial use of limestone filler with calcium sulphoaluminate cement. Constr. Build. Mater. 2012, 26, 619627.

[11] A.R. Estabraght, m. Katibi and A.A. Javadi, 2016, Effect of Cement on Treatment of a Clay Soil Contaminated with Glycerol, Journal of Materials in Civil Engineering, ASCE, Volume 28, issue 4 - April 2016, pp 126-135

[12] Tugino. 2010. Model Kuat Tekan dan Tarik Proporsi Tras Muria Dengan Kapur Untuk Kapur Untuk Bahan Dasar Mortar. Jurnal Teknik Sipil dan Perencanaan. 12(1): 1-10.

[13] Mohammad Ali Mosaberpanah, Özgür Eren, 2017, Effect of quartz powder, quartz sand and water curing regimes on mechanical properties of UHPC using response surface modeling, Advances in Concrete Construction, Vol. 5, No. 5 (2017) 481-492

[14] McCormac, J. C. (2003). Desain Beton Bertulang . Jakarta : Penerbit Erlangga

[15] Nhat-Duc Hoang1 and Anh-Duc Pham2, 2016, Estimating Concrete Workability Based on Slump Test with Least Squares Support Vector Regression, Hindawi Publishing Corporation Journal of Construction Engineering Volume 2016, Article ID 5089683, 8 pages $1-8$

[16] Agus Purwati,, Sholihin As'ad, , Sunarmasto, 2014, Pengaruh Ukuran Butiran Agregat Terhadap Kuat Tekan dan Modulus Elastisitas Beton Kinerja Tinggi Grade 80, e-Jurnal Matriks Teknik Sipil Vol. 2 No. 2/Juli 2014 pp 58-63

[17] Yalley P P and Sam A,2018, Effect of Sand Fines and Water/Cement Ratio on Concrete, 
Civil Engineering Research Journal (CERJ), Volume 4 Issue 3 - April 2018, pp 001 -007

[18] Ismaeel H. Musa Albarwary Ziyad N. ShamsulddinAldoski Lawe nd K. Askar, 2017, Effect of Aggregate Maximum Size upon Compressive Strength of Concrete, Journal of University of Duhok, Vol. 20 , No.1(Pure and Eng. Sciences), Pp 790 -797, 2017

[19] S.Sneka , M.Nirmala2, Dr.G.Dhanalakshmi, 2018, Size Effect of Aggregate The Mecanical Properties Of Cocrete, International Research Journal of Engineering and Technology (IRJET) Volume: 05 Issue: 02 | Feb pp-2093-2096

[20] Renjuraj R, Shabana A,Salman Faris,Chinju G Mohan, Shahana M S, Archa M S, Sarath S, Effect on Workability and Strengthof Concrete due to Variation in Mixing Water Temperature, International Journal of Scientific \& Engineering Research, Volume 7, Issue 4, April 2016, PP 185-188

[21] Al-Humaiqani Mohammed M, Ahmed B. Shuraim and Raja Rizwan Hussain. Effect of
Compressive Strength on $\gamma$-Radiation Attenuation Coefficients for High Performance Concrete. International Journal of Engineering and Technology, 2013, 5(5): 566

[22] C. Liana,, Y. Zhugeb, S. Beecham,2011, The relationship between porosity and strength for porous concrete, Construction and Building Materials journal homepage: www.elsevier.com/locate/conbuildmat,25(20 11) 4294-4298

[23] Xudong Chen, Shengxing Wu, Jikai Zhou, 2013, Influence of porosity on compressive and tensile strength of cement mortar, Construction and Building Materials journal homepage:

www.elsevier.com/locate/conbuildmat, $\quad 40$ (2013) 869-874

[24] Papzan Ali and Taksiah AM. The effects of steam curing on porosity of high strength concrete containing metakaolin. Journal of American Science, 2012, 8(11): 518-522. 